\title{
Agnieszka DZIĘCIOŁ-PĘDICH
}

Uniwersytet w Białymstoku

lumriel@gmail.com

\section{THE IMAGE OF THE CORPORATE WORLD IN BUSINESS ENGLISH SPEAKING EXERCISES AT UPPER INTERMEDIATE LEVEL}

\section{INTRODUCTION}

Contemporary business English course books claim to bring the real world of international business into language classrooms. Their authors argue that they can be used both by students who are preparing for a career in the world of business and by those who already have professional experience but want to improve their communication skills in English. In-service learners of business English can fall back on their professional experience to verify the picture of the international business world presented in course books, but pre-service students might find it difficult to assess how accurate communication patterns, types of interactions, as well as the participation of men and women in the world of business are. In fact, for language learners with no professional experience business English course books might be the first source of information on how business people communicate (especially as regards oral communication) and participate in corporate environments. If not chosen or adapted properly, business English course books might present a distorted picture of business environments, and consequently inadequately prepare pre-service students for successful participation in the labour market. 


\section{BUSINESS ENGLISH STUDENTS' COMMUNICATIVE NEEDS}

The world of international business is so dynamic and complex that it escapes a simple description. Nevertheless, there are some characteristics that are worth mentioning, especially for the purposes of teaching business English to pre-service students.

One of the first things pre-service students should be made aware of is the fact that English is the only major language of global business (Graddol 2006: 62), where it acts as a lingua franca between non-native speakers: if a German sales manager is going to do business with his or her Chinese counterpart, they are likely to use English to negotiate the deal (Graddol 2000: 13).

When English becomes the lingua franca of the contemporary world (Seidlhofer 2005: 339) and the world of business (Nickerson 2005: 367), native speaker standards of correctness no longer apply to effective communication (Walker 2015: 44). As Andrewes (2012: 7) observes: “(...) we are witnessing here the evolving usage of English as a Lingua Franca, the global medium of communication between NNSs (non-native speakers), where communicative competence develops with little more than a passing reference to L2 norms".

Interestingly, English as a lingua franca (EFL) is likely to display identity markers such as code-switching or the explicit use of nativised forms when it is used in a local setting. However, when it is used for international communicative exchanges, the speakers will consciously make an effort to avoid local and nativised norms and expressions (Kickpartick 2007: 168). Finally, the purpose and goal of an EFL communication will dictate the degree to which a common cultural basis between EFL speakers needs to be negotiated (Amvela 2000: 358).

In the discussion of the international world of business it is also worth mentioning two types of working English (Mercer 1996). The first type of working English represents communicative exchanges between professionals and workers who represent the same line of work. Such people have specialised language needs, including particular items of vocabulary. Such groups of workers form a community which is characterized by a variety of styles and levels of formality specific to the occupation. Even though communicative exchanges between a supervisor and a factory employee might differ from the ones between middle and senior managers, they all may be a part of the same discourse community. 
The second type of working English implies communication with people who are from outside the trade or profession. This type of working English is a consequence of the growing variety of service industries and the number of employees who are obliged to project a corporate image when they communicate with the public. Many employers require their employees to communicate with the company's clients and customers in a particular way, as the language the employees use is an integral part of the 'services' offered (Graddol 2000: 43).

Pre-service students should also be made aware that various subdisciplines, such as economics, marketing, management, or accountancy, vary in their use of language. In fact, every discipline is characterised by a repertoire of genres which members of other disciplinary or professional communities are unlikely to use (Bhatia 2004).

Discussion of the international business world cannot be limited only to linguistic issues. One of the non-linguistic topics to be covered with pre-services students learning business English is the role women and men in the labour market.

In the 21st century women participate in labour markets on an unequal basis with their male colleagues: in 2013 the employment-topopulation ratio for men stood at 72.2 per cent, while the ratio for women was 47.1 per cent. (Global employment trends... 2014: 19). On a global scale men are paid more than women. On average, the majority of women earn from 60 to 75 per cent of men's wages (Internet source 1), as it is more likely that women will be wage workers and unpaid family workers. Moreover, women are more likely than men to engage in low-productivity activities and to find employment in the informal sector. Men, on the other hand, enjoy greater mobility in the formal sector (World Development Report... 2012: 79). Global growth and competitiveness has been driven by the growing participation of women in the labour market. However, there are still fewer than $5 \%$ female CEOs of publically listed companies in OECD countries (Women in Business and Management... 2015: 7).

Successful participation in the world of international business requires, among other things, a good command of spoken English. Most students can put business English speaking skills into practice only when they enter the labour market, and only if they find a job which requires them to use English for oral communication (Dzięcioł-Pędich 2015: 70). It seems reasonable to devote as much time as possible in the language 
classroom to developing skills which students are unable to practice on their own.

Business English course books have become the major source of information on how the world of international business communicates, especially for pre-service students for whom business English courses at tertiary level offer one of their only opportunities to get an insight into the corporate world.

Speaking exercises in business English course books might shape students' perceptions of the corporate world as they develop skills students are not yet socially familiar with. Furthermore, pre-service students, due to their lack of professional experience in the international labour market, might not be able to assess how accurately speaking exercises reflect actual communicative exchanges in multinational corporations. Finally, speaking exercises might shape students' perceptions on the participation of men and women in the world of business. Hence, the need for thorough evaluation and then adaptation of business English course books on the market.

\section{TYPES OF MATERIAL EVALUATION}

There are two basic types of material evaluation, i.e. predictive evaluation (Cunnigsworth 1995, Ellis 1997) and retrospective evaluation (Cunnigsworth 1995, Ellis 1997). Predictive evaluation helps teachers select appropriate materials. In retrospective evaluation data come from the actual application of the materials in the classroom (Ellis 1997). Predictive evaluation can be subdivided into impressionistic evaluation and indepth evaluation. Impressionistic evaluation means the analysis of a given course book or materials on the basis of a general impression. In-depth evaluation, on the other hand, means thorough scrutiny of, among other things, the treatment and presentation of the skills, the sequencing and grading of the materials, the type of reading, listening, speaking and writing materials contained in the materials, appropriacy of tests and exercises, self-study provision, and teacher-learner 'balance' in the use of the materials (McDonough, Shaw and Masuhara 2013).

In-depth evaluation can be done with the help of checklists, which, according to Cunnighsworth (1995), are an economic and systematic way of ensuring that all relevant items will be included in the evaluation. 
According to Demir and Ertaş (2014: 245), a checklist can be qualitative or quantitative: "When designed in the form of quantitative scales, they allow for an objective evaluation of a given coursebook. Qualitative checklists, on the contrary, elicit subjective information on the quality of course books by directing open-ended questions". A variety of checklists for course book evaluation which take into account a variety of items have been developed, but it seems that qualitative checklists are more common. For instance, Grant (1987) developed a checklist called the CATALYST test - the letters of this acronym stand for communicative, Aims, Teachability, Availability, Level, Your impression, Students' interest, and Trying and testing. Tanner and Green (1998) proposed a MATERIALS checklist: Method, Appearance, Teacher-friendliness, Extras, Realism, Interestingness, Affordability, Level and Skills. McDonough, Shaw and Masuhara (2013) think that such items as the treatment and presentation of the skills, the sequencing and grading of the materials, the type of reading, listening, speaking and writing materials contained in the materials, appropriacy of tests and exercises, self-study provision, and teacher-learner 'balance' in the use of the materials should be included in the checklist for an in-depth evaluation of a course book or materials.

It seems that the presence of a given item in an evaluation check list depends on the purpose of the evaluation and the context in which it takes place. The same should be true for the analysis of cultural and social values in general English language course books and business English course books.

\section{CULTURAL AND SOCIAL VALUES IN ENGLISH LANGUAGE COURSE BOOKS}

The primary aim of course books is to facilitate language learning, and therefore their authors try to represent the language as it is used in real life. In consequence, course books "contain subject matter and deal with topics of various kinds" (Cunningsworth 1995: 86). Thus course books communicate, directly or indirectly, a set of values characteristic for their make-up. This is part of the so-called 'hidden curriculum', an unstated and undisclosed part of educational curricula which exerts a significant influence on learners (Aleksandrowicz-Pędich 2003: 123). 
Value systems in course books, even though unstated and undisclosed, can affect both learners' general attitudes and their attitudes towards learning English. As Arikan (2005: 38) observes: "Because schools are places in which teachers, course books, classroom materials, activities, and attitudes of all members of a given school or classroom contribute to the cognitive and emotional formation of students through knowledge based and value-laden practices, an infinite number of messages or values are passed on to students. Such values, then, may turn into stereotypical thinking of students towards others in society, inevitably building onto the malpractices such as hatred, intolerance, or belittling of others, resulting in the erosion in societal peace and solidarity". For that reason, cultural, ideological and social values in course books have been widely researched from a variety of perspectives.

\subsection{NATIONAL CULTURES IN COURSE BOOKS}

Kożuch, Muciek and Wawrzyczek (1995 in Aleksandrowicz-Pędich 2003) analysed the following course books: Blueprint, Strategies, and Kernel and discovered that they do not present a reliable picture of modern British culture, but reflect intellectual and political obsessions related to post-colonial problems of contemporary Great Britain.

Toprak and Aksoyalp (2014) analysed the following teaching series (from beginner to advanced level): New English File, New Headway, Language Leader, and Top Notch to explore the extent and number of cultural representations present in course books, as well as the distribution of cultural representations across different English-speaking countries (i.e. the UK, the USA, Australia, Canada, and New Zealand). Not surprisingly, the findings showed that the majority of cultural elements that can be found in course books belonged to the UK and the USA, while the other English speaking countries remained underrepresented.

\subsection{THE WORLD OF WORK IN COURSE BOOKS}

Gray (2010) analysed Streamline Connections, Building Strategies The New Cambridge English Course 2, and New Edition New Headway Intermediate to research representations of the world of work in English course books from the 1970s up to the present. The analysis showed that these course books impose on students an image of white-collar professional 
life, which is one of intense individualism, where work is perceived as a path to self-fulfilment determined largely by personal choice.

\subsection{SOCIAL ACTORS IN COURSE BOOKS}

Günay (2015) analysed the following intermediate course books: Face2Face, English Unlimited, New English File, English Result, Speakout, Global, and Upstream to research visual depictions of social actors presented in these course books. The author investigated photographs with people in them with regard to the relations of social distance, involvement, power, and interaction between the depicted social actors and their viewers, as well as the emergent practices of exclusion, role allocation, genericization, specification, assimilation, individualization, and categorization. The analysis showed, among other things, that social actors who are 'socially different' are repeatedly shown in assimilative ways, whereas socials actors who represent the reference group are pictured individually.

\subsection{SEXISM AND GENDER IN COURSE BOOKS}

As far as the analysis of cultural values is concerned, it seems that sexism and gender are the most frequently researched phenomena, for example by De Crow (1972), Coles (1977), Britton and Lumpkin (1977), Michel (1986), Sleeter \& Grant (1991), Cunningsworth (1995), Davies 1995), Filak (2002), Arikan (2005), Aydinoğlu (2014), Lewandowski (2014), and Şeker and Dinçer (2014).

In recent years, Filak (2002) analysed EFL course books which were available to Polish learners of the English language in 1946-2001. The main aim of the study was to identify the negative gender stereotypes, which give rise to sex discrimination, and to demonstrate how these representations changed over fifty years. The results of the study showed that the texts in these course books depreciate and discriminate one of the sexes; they are "carriers" of negative stereotypes. Women in almost all the analysed course books are presented in subordinate roles, as a housewife or secretary, being told what to do. They are presented as stupid, dependent, whining and fearful. Men, on the contrary, are portrayed as active and aggressive.

Arikan (2005) analysed New Headway and Think Ahead to First Certificate to study how age, social class, and gender are represented in the visual materials published in ELT course books. Arikan also wanted to 
learn what can be said about such representations as a part of social criticism in regard to the cultural and social messages given through such representations. The analysis revealed that the majority of visual materials in these course books show a middle class which is represented by middle aged individuals with equal proportions between both genders. However, a further analysis of these materials showed that ageist tendencies are clearly visible in course books: the elderly "are not presented as whole persons existing with many qualities other than their ages" (Arikan 2005: 35). As regards gender, the research showed that women are underrepresented in visual materials, and that child rearing and doing housework is normally associated with women. Moreover, in nuclear families it is the father who is the head of the family, and the mother is responsible for children and household chores. Gender separation is also visible in the field of sport: men play basketball, golf and soccer, and go cycling, snowboarding, fishing, stretching and running, whereas women do aerobics, stretching, yoga, go running and skiing, and play volleyball. Finally, as regards social class, the research revealed that these course books project images and values characteristic of the middle class. The lowest and marginal classes are not visible, whereas the rich and celebrities are given success stories.

Aydinoğlu (2014) analysed texts and illustrations in Fun with Teddy and Joyful English-1 Book 1 and Book 2 course books to analyse, among other things, the distribution of the presence of female and male characters, types and distribution of jobs for female and male characters in visual data, and types and distribution of activities for female and male characters in visual data. The study showed that the biggest difference in the approach to gender bias is found in the distribution of jobs for female and male characters. While men predominantly have more jobs in Fun with Teddy, women have the advantage over men in Joyful English-1 . However, the overall results show that women cannot catch up with men.

Lewandowski (2014) analysed six grammar books: A Proficiency Course in English, A Practical English Grammar, Advanced English Practice, Advanced Grammar in Use, A Self-Study Reference and Practice Book for Advanced Learners of English. With Answers, Advanced Language Practice with Key. English Grammar and Vocabulary, Advanced Learners' Grammar. A SelfStudy Reference $\mathcal{E}$ Practice Book with Answers to investigate whether and how the images of men and women have changed following the dissemination of guidelines for non-sexist language and equal treatment of 
the two genders in English language educational materials. Contrastive analysis of sentences from these course books has shown that the presentation of the two genders in recent publications is much less stereotypical than in 20th century course books.

Şeker and Dinçer (2014) analysed the following pre-intermediate course books: Speak Out, Outcomes, New Success, and Language Leader to identify and categorize stereotyped roles for men and women. The analysis showed that as regards personality features, intellect is mainly attributed to men, and women are responsible for social relationships. As for professional qualifications, men work in business, medicine, politics and the arts, whereas women work almost solely in educational settings. When it comes to physical appearance, female characters in the analysed course books are short and young with blond hair and pretty faces. Male characters, on the other hand, are tall and good-looking.

Analyses of different course books show that cultural and social values are usually presented in a stereotypical way which might present a distorted picture of reality. And yet, cultural content in course books should be realistic, up-to-date and representative of, among other things, different age, gender, mentality, interest, class and family groups (Edelhoff 1987 in Sercu 1998).

It seems that the majority of studies on cultural and social values focus on general English course books. However, in view of the fact that business English courses are becoming increasingly popular, business English course books should also be analysed from this point of view.

\section{RESEARCH DESCRIPTION}

The purpose of the research was to analyse sections of business English course books which help students develop their business English speaking skills to find out the image of the corporate world created in the minds of the students through these activities.

\subsection{RESEARCH AIMS AND INSTRUMENT}

The research was motivated by the following questions:

- What business English speaking skills are students taught? To what degree are these skills applicable across various situational and cul- 
tural contexts? What registers are students taught to use? Are they told when and how to apply them?

- What variety of English is presented in speaking sections?

- What is the proportion between female and male speakers in the recordings which introduce the language structures used in these sections?

- What are male and female speakers' roles in the world of business as presented in the recordings?

The research questions were later turned into a checklist, which became the main research instrument.

\subsection{RESEARCH SAMPLE}

Speaking sections in the following course books were analysed for the purpose of the research:

- In company 3.0 Upper intermediate Student's Book Pack (2014) by Mark Powell and John Allison

- The Business 2.0 Upper-intermediate Student's Book (2013) by John Allison and Jeremy Townend with Paul Emmerson

- Market Leader Upper Intermediate Business English Course Book (2011) by David Cotton, David Favley and Simon Kent

- Business Result Upper-intermediate Student's Book (2008) by Michael Duckworth and Rebecca Turner

- Intelligent Business Coursebook Upper Intermediate (2006) by Tonya Trappe and Graham Tullis

- ProFile 3 Upper-Intermediate Student's Book (2005) by Jon Naunton Usually, a business English course book contains a section devoted to developing speaking skills which is structured in more or less the following way:

- an introductory element which might take the form, for instance, of a question to be discussed in pairs or groups, a set of statements to be discussed in pairs or in groups, a short explanation of an idea/skill/job presented in the section.

- a recorded conversation/conversations between two or more people which contain(s) the language structures students will be practising. Sometimes, students listen to one speaker giving, for example, a presentation. Having listened to the recording, students have to answer either some comprehension questions or questions which focus di- 
rectly on the structure of the phrases being used, or questions which direct students' attention to the paralinguistic features of the presented discourse.

- an exercise which requires from students conscious manipulation of the structures used in the recording, e.g. completing the missing words, or sentence transformation.

- an exercise during which students are supposed to role play a similar situation to the recording and use similar or the same structures as the speakers from the recording did.

The presented structure might differ between course books, but in general the idea is that sections which develop speaking skills have a presentation-practice-production framework.

The research focused on course books from the last ten years. The sample includes course books from teaching series which are easily available on the Polish market and seem to be frequently used by Polish ESP teachers who work in institutions of higher education, as shown by the analysis of language syllabi - e.g. at the Jagiellonian University (Internet source 2), at the University of Business and Administration in Gdynia (Internet source 3), or at the Technical University in Opole (Internet source 4).

The research focused on upper intermediate business English course books for two main reasons. First of all, in the public sector of education in Poland business English courses are usually offered by institutions of higher education when students are in the first or second year. Their level of English is supposed to be at least B1 level, as the secondary school leaving exam, the so-called 'Matura', tests language skills at this level. Therefore, it seems reasonable to work with upper-intermediate course books with secondary school graduates. Secondly, sound general linguistic competence seems to be the best basis for teaching a professional variety of a language (Zawadzka 2004: 141). Hence, the upper intermediate level.

\subsection{DISCUSSION OF THE FINDINGS}

\subsubsection{SKILLS}

Table 1 presents selected speaking skills in speaking sections of the analysed course books. Each course book contains a much wider variety of skills, but the ones that appear in almost every course book are: 
TABLE 1. Selected speaking skills in business English course books

\begin{tabular}{|c|c|c|c|c|c|}
\hline The business & In company & Profile & $\begin{array}{c}\text { Market } \\
\text { leader }\end{array}$ & $\begin{array}{l}\text { Intelligent } \\
\text { business }\end{array}$ & $\begin{array}{c}\text { Business } \\
\text { result }\end{array}$ \\
\hline $\begin{array}{l}\text { Interviewing } \\
\text { Telephoning } \\
\text { Delivering } \\
\text { presentations } \\
\text { Coaching } \\
\text { Communicat- } \\
\text { ing in meet- } \\
\text { ings } \\
\text { Negotiating } \\
\text { a compromise }\end{array}$ & $\begin{array}{l}\text { Building } \\
\text { rapport } \\
\text { Delivering } \\
\text { presentations } \\
\text { Dealing with } \\
\text { complaints } \\
\text { Managing } \\
\text { meetings } \\
\text { Making an } \\
\text { effective } \\
\text { business } \\
\text { presentation } \\
\text { Teleconferenc- } \\
\text { ing }\end{array}$ & $\begin{array}{l}\text { Speaking with } \\
\text { conviction } \\
\text { Participating } \\
\text { in meetings } \\
\text { Dealing with } \\
\text { customer com- } \\
\text { plaints } \\
\text { Making pre- } \\
\text { sentations } \\
\text { Welcoming } \\
\text { visitor } \\
\text { Handling in- } \\
\text { terview ques- } \\
\text { tions }\end{array}$ & $\begin{array}{l}\text { Brainstorming } \\
\text { Networking } \\
\text { Cold-calling } \\
\text { Negotiating } \\
\text { Making a pre- } \\
\text { sentation }\end{array}$ & $\begin{array}{l}\text { Building work- } \\
\text { ing relation- } \\
\text { ships } \\
\text { Briefing } \\
\text { Story telling/ } \\
\text { personal nar- } \\
\text { ratives } \\
\text { Prioritising } \\
\text { Handling con- } \\
\text { flict } \\
\text { Persuading } \\
\text { Motivating }\end{array}$ & $\begin{array}{l}\text { Making small } \\
\text { talk } \\
\text { Making and } \\
\text { responding to } \\
\text { suggestions } \\
\text { Presenting an } \\
\text { idea, product, } \\
\text { service, future } \\
\text { Participating } \\
\text { in meetings } \\
\text { Exchanging } \\
\text { information, } \\
\text { making } \\
\text { a follow-up } \\
\text { call }\end{array}$ \\
\hline
\end{tabular}

making a presentation, participating and communicating in meetings, various forms of establishing contacts and rapport, handling interviews and dealing with customer complaints. Speaking sections help students develop business English speaking skills in general business situations. The majority of conversations in the recordings which introduce language structures and in follow-up role-playing exercises take place among people who are on a similar level of the corporate hierarchy, most often among colleagues. The language in these exchanges could be labelled as semi-formal. Students are hardly ever given the opportunity to practise more formal styles of communication which might sometimes be required depending on the relations of the speakers and the cultural context. Consequently, they do not really have the opportunity to learn when a given style might be applicable. For instance, in a large company with an extended management structure or a more hierarchical corporate culture the power distance between an employee and a high ranking manager may require a more formal style of communication. Similarly, since English is a lingua franca, it is worth noting that in certain cultures a formal style of communication is required in contacts with immediate superiors or even among colleagues.

This problem applies not just to formal and semi-formal styles of communication, but to all language content. Although they seem fairly universal, it is uncertain to what extent the styles, phrases and types 
of interactions presented in course books apply across various speakers, branches of industry, and national and corporate cultures.

It should be stressed here that in Intelligent business after each section developing speaking skills there is a short section, Cultures at work, which shows students that national cultures might affect communication styles, and encourages students to reflect on their own culture.

The question of the transferability of business English speaking skills is not the only problem encountered in language classrooms. Huhta et al. (2013: 8) argue that pair work, information gap activities or other practices of the Communicative Approach which are used in developing speaking skills cannot adequately prepare students for the "multi-participant, multi-professional, multi-location information exchanges of the modern workplace".

\subsubsection{LANGUAGE VARIETY IN THE COURSE BOOKS}

Although it is not explicitly stated, all the analysed course books were written in British English in terms of vocabulary items and grammar structures. This is hardly surprising as all of them come from British publishers. Neither English as a lingua franca, nor any other World Englishes are used anywhere in the course books.

Students who use business English course books available on the market might get the impression that the international world of business speaks grammatically correct British English with a variety of accents. They are not made aware that English has become the lingua franca of the business world. On one hand, the insistence on a standard variety of language in course books does not prepare students for the way nonnative speakers communicate. On the other hand, the difficulty of differentiating between authentic non-standard alternatives and persistent errors, as well as the lack of a uniform lingua franca core shared by fluent bilinguals from different first-language backgrounds (Shim 2009: 113 in Sowden 2011: 91) makes it difficult for English as a lingua franca to be the language of course books. Nevertheless, pre-service students should be made aware of differences in communication styles between native and non-native speakers. Even though Ehrenreich (2010: 408) might argue that learning to cope with the challenges of communication in English as a lingua franca seems to happen most effectively in business 'communities of practice' rather than in business English classrooms, students should be 
equipped with skills that would enable them to negotiate meaning with other bilinguals.

It seems that the only linguistic indication, in exercises which develop speaking skills, that the world of business is truly international are accents used by the speakers in the recordings which introduce language structures. Pre-service students are aware of the variety of accents as they can hear various speakers in the recordings accompanying general English course books. However, it should be mentioned that in the case of business English exercises accents might impede the understanding of the message as speaking exercises might concentrate on situations students are not yet socially familiar with and cannot rely on situational context to figure out the meaning.

\subsubsection{MALE AND FEMALE SPEAKERS}

TABLE 2. Proportion of male and female speakers

\begin{tabular}{|l|c|c|c|c|c|c|}
\hline & $\begin{array}{c}\text { The } \\
\text { business }\end{array}$ & $\begin{array}{c}\text { In } \\
\text { company }\end{array}$ & Profile 3 & $\begin{array}{c}\text { Market } \\
\text { leader }\end{array}$ & $\begin{array}{c}\text { Intelligent } \\
\text { business }\end{array}$ & $\begin{array}{c}\text { Business } \\
\text { result }\end{array}$ \\
\hline $\begin{array}{l}\text { Female } \\
\text { speakers }\end{array}$ & 14 & 54 & 13 & 15 & 25 & 24 \\
\hline $\begin{array}{l}\text { Male } \\
\text { Speakers }\end{array}$ & 17 & 79 & 12 & 16 & 35 & 29 \\
\hline
\end{tabular}

Table 2 illustrates the number of female and male speakers in recordings which introduce the language structures students are expected to practice. On average, the number of male speakers is only slightly higher, with the exception of In company, where there are 25 more male than female speakers. In company also has the highest number of speakers and, what follows, the highest number of recordings which introduce language structures, because this course book is the most focused on developing business English speaking skills. In Intelligent business female speakers are also outnumbered, but the difference is not as big as in In company: there are 10 more male than female speakers. Moreover, the majority of conversations take place between women and men, and both genders initiate communication in all the analysed course books.

Table 3 presents the roles of female and male speakers in recordings which introduce language structures students are expected to master. 
TABLE 3. Male and female roles in speaking sections

\begin{tabular}{|c|c|c|c|c|c|}
\hline The business & In company & Profile 3 & $\begin{array}{l}\text { Market } \\
\text { leader }\end{array}$ & $\begin{array}{l}\text { Intelligent } \\
\text { business }\end{array}$ & $\begin{array}{l}\text { Business } \\
\text { result }\end{array}$ \\
\hline \multicolumn{6}{|c|}{ Female roles } \\
\hline $\begin{array}{l}\text { Interviewer } \\
\text { Store manager } \\
\text { Customer } \\
\text { Sales represen- } \\
\text { tative } \\
\text { Presentation } \\
\text { specialist } \\
\text { Company's } \\
\text { CFO } \\
\text { Representative } \\
\text { of a fair trade } \\
\text { manufacturer }\end{array}$ & $\begin{array}{l}\text { Chair of } \\
\text { a meeting } \\
\text { Customer ser- } \\
\text { vice advisor } \\
\text { Board member } \\
\text { Company } \\
\text { executive }\end{array}$ & $\begin{array}{l}\text { Employee } \\
\text { welcoming } \\
\text { visitors to } \\
\text { the company } \\
\text { Interviewer } \\
\text { Customer ser- } \\
\text { vice employee }\end{array}$ & $\begin{array}{l}\text { Head of de- } \\
\text { partment } \\
\text { Chief execu- } \\
\text { tive of a hotel } \\
\text { group } \\
\text { Headhunter } \\
\text { Head buyer } \\
\text { Chief negotia- } \\
\text { tor }\end{array}$ & $\begin{array}{l}\text { Journalist } \\
\text { Project man- } \\
\text { ager } \\
\text { Employee } \\
\text { preparing } \\
\text { a market re- } \\
\text { port/market } \\
\text { research } \\
\text { Line manager }\end{array}$ & $\begin{array}{l}\text { Employee pre- } \\
\text { senting a com- } \\
\text { pany's project } \\
\text { Employee or- } \\
\text { ganizing a trip } \\
\text { for reporters } \\
\text { Regional cus- } \\
\text { tomer service } \\
\text { manager } \\
\text { Team leader in } \\
\text { a financial ser- } \\
\text { vices company } \\
\text { Department } \\
\text { leader } \\
\text { Employee of } \\
\text { an insurance } \\
\text { company } \\
\text { Person con- } \\
\text { ducting an } \\
\text { appraisal }\end{array}$ \\
\hline \multicolumn{6}{|c|}{ Male roles } \\
\hline \begin{tabular}{|l|} 
Interviewee \\
Department \\
supervisor \\
Customer \\
Sales represen- \\
tative \\
Representative \\
of a workers' \\
cooperative
\end{tabular} & $\begin{array}{l}\text { Director of an } \\
\text { advertising } \\
\text { agency } \\
\text { Chair of } \\
\text { a meeting } \\
\text { Client } \\
\text { Board member } \\
\text { Company } \\
\text { executive }\end{array}$ & $\begin{array}{l}\text { Management } \\
\text { consultant } \\
\text { Interviewee } \\
\text { Angry cus- } \\
\text { tomers }\end{array}$ & $\begin{array}{l}\text { Marketing } \\
\text { Director } \\
\text { Chief Negotia- } \\
\text { tor } \\
\text { Sales Manager } \\
\text { Exporter } \\
\text { Bank manager } \\
\text { Presenter of } \\
\text { a television } \\
\text { consumer } \\
\text { protection } \\
\text { programme }\end{array}$ & $\begin{array}{l}\text { Journalist } \\
\text { Employee } \\
\text { responsible } \\
\text { for product } \\
\text { development } \\
\text { work } \\
\text { Chair of } \\
\text { a briefing } \\
\text { session } \\
\text { Team leader } \\
\text { Production } \\
\text { manager } \\
\text { Consultant } \\
\text { Team manager } \\
\text { Supplier }\end{array}$ & $\begin{array}{l}\text { Owner of } \\
\text { a translation } \\
\text { agency } \\
\text { Regional cus- } \\
\text { tomer service } \\
\text { manager } \\
\text { Leader of } \\
\text { a team } \\
\text { in a financial } \\
\text { services com- } \\
\text { pany } \\
\text { Department } \\
\text { leader } \\
\text { Person re- } \\
\text { sponsible for } \\
\text { a team of tele- } \\
\text { com engineers } \\
\text { Web designer }\end{array}$ \\
\hline
\end{tabular}

In Market Leader, In company, Profile 3, The Business and Intelligent business male and female roles are usually specified in instructions to exercises. In Business Result male and female roles are presented in a short 
text titled Context which always precedes the section devoted to developing speaking skills.

The analysis of speaking sections shows that in the world of business (as presented in these course books) women and men have similar roles and might occupy equally high positions on the corporate ladder. If they occupy similar positions, both men and women can be presented as the more experienced or knowledgeable party. In most conversations reversing the gender of the speakers would not affect the conversations. This has the practical advantage of making it easier for male and female students to role play these interactions.

Contrary to what statistics claim, such proportions and the roles presented suggest equal participation of female and male speakers in the world of business. On one hand, the picture presented in the course books is not entirely accurate, but on the other hand it may encourage more egalitarian attitudes upon entering the job market. In fact, it is probably political correctness more than anything else that encourages course book publishers to present gender roles like this.

\subsection{PEDAGOGICAL IMPLICATIONS}

Students who use business English course books might get the impression that the corporate world speaks only correct British English with a variety of accents. Students might also think that men and women participate equally in the world of international business and enjoy similar positions on corporate ladders. This might be a slight exaggeration, but it cannot be denied that business English course books understate the enormous variation in style and language which exists in the world of international business. This means that, apart from using business English course books, language teachers should use authentic materials which include factually accurate and up-to-date cultural and social information. Learners should also be made stereotype-conscious and granted freedom in questioning ideological tendencies implicit in the material (Huhn 1978 in Byram 1989).

As regards oral communication, pre-service students should be made aware of the variety of world Englishes and the existence of English as a lingua franca by frequent exposure to, for instance, business English podcasts easily accessible on the websites of major newspapers and economics magazines. They should also be made aware that formal and 
informal language may affect the effectiveness of business encounters, and for that reason they should practice different communicative styles and registers.

\section{CONCLUSIONS}

In order to be effective, teaching needs a sound description of the target situation (Zhang 2013: 2); that is why business English teachers cannot rely solely on course books, as they would present their students with an unrealistic picture of the corporate world. Moreover, business English teaching should constantly bridge the gap between the classroom and the workplace (Bhatia 2004) through the use of a variety of authentic materials and case studies, as business communication frameworks and models presented in contemporary course books are becoming obsolete and losing touch (Bhatia and Bremner 2012: 436) with the intercultural, multimodal, virtual, and strategic world of work.

The author would like to thank Pearson and Macmillan publishing houses for making their course books available.

\section{BIBLIOGRAPHY}

Aleksandrowicz-Pędich, L., 2003, “Ukryty program w podręcznikach do nauki języków obcych", in: Reforma w nauce języka obcego. Nowe programy i podręczniki, ed. Hanna Komorowska, Warszawa, 123-131.

Amvela, E.Z., 2000, "Lingua franca", in: Routledge Encyclopaedia of Language Teaching and Learning, ed. M. Byram, London, 356-359.

Andrewes, S., 2011, "Communicative language learning: Communicative for what purpose?", Modern English Teacher 20(2), 5-13.

Andrewes, S., 2012, "We are what we wear]], Modern English Teacher 21(2), 5-8.

Arikan, A., 2005, "Age, gender and social class in ELT coursebooks: a critical study", Hacettepe University Journal of Education 28, 29-38.

Aydinoğlu, N., 2014, "Gender in English language teaching coursebooks", Procedia - Social and Behavioral Sciences, 158, 233-239.

Bhatia, V.K., 2004, Worlds of Written Discourse. A Genre-Based View, London.

Bhatia, V.K, Bremner, S., 2012, "English for Business Communication", Language Teaching 45(4), 410-445. 
Britton, G., Lumpkin, M., 1977, "For Sale: Subliminal bias in textbooks", The Reading Teacher, 31(1), 40-45.

Byram, M., 1989, Cultural Studies in Foreign Language Education, Clevedon.

Coles, G., 1977, “Dick and Jane grow up: Ideology in adult basic education readers", Urban Education, 12(1), 37-53.

Cunningsworth, A., 1995, Choosing your coursebook, Oxford.

Davies, B., 1995, Gender Bias in School Textbooks, London.

De Crow, K., 1972, “Look, Jane, Look! See Dick Run and Jump! Admire him!”, in: ed. S. Anderson, Sex differences and Discrimination in Education, Ohio, 44-49.

Demir, Y., Ertaş, A., 2014, "A Suggested Eclectic Checklist for ELT Coursebook Evaluation", The reading Matrix, 14(2), 243-252.

Dzięcioł-Pędich, A., 2015, "Challenges of Developing Speaking Skills in Business English Courses at the Tertiary Level", in: Productive Foreign Language Skills for an Intercultural World. A Guide (not only) for Teachers, ed. M.B. Paradowski, Frankfurt am Main, 63-77.

Ehrenreich, S., 2010, "English as a Business Lingua Franca in a German Multinational Corporation: Meeting the Challenge", Journal of Business Communication 47, 408-431.

Ellis, R., 1997, "The empirical evaluation of language teaching materials", ELT Journal, 51(1), 36-42.

Filak, A., 2002, "Men and Women Between Cultures: Gender Stereotypes in EFL Coursebooks in Poland (1947-2001)", NeoLit Online. A culture in-Between, $1(2), 1-49$.

Global employment trends 2014. Risk of a jobless recovery?, 2014, Geneva: International Labour Office. Available at: http://www.ilo.org/wcmsp5/groups/ public/---dgreports/---dcomm/---publ/documents/publication/wcms_233 953.pdf Accessed: 22.08.2015.

Graddol, D., 2000, The Future of English? A guide to forecasting the popularity of the English language in the $21^{\text {st }}$ century, The British Council. Available at: https://microsites.bournemouth.ac.uk/business-postgraduate/files/2014/ 09/CIGBE-The-Future-of-English.pdf. Accessed: 22.08.2015.

Graddol, D., 2006, English Next. Why global English may mean the end of 'English as a Foreign Language, The British Council. Available at: http://english agenda.britishcouncil.org/sites/ec/files/books-english-next.pdf. Accessed: 22.08.2015.

Grant, N., 1987, Making the most of your textbook, Oxford.

Gray, J., 2010, "The Branding of English and The Culture of the New Capitalism: Representations of the World of Work in English Language Textbooks", Applied Linguistics 31(5), 714-733.

Günay, D., 2015, “Who Populates the Visual Landscape of the ELT Coursebooks?: A Photo Analytical Exploration", Journalism and Mass Communication, 5(8), 388-404. 
Huhta, M., Vogt, K., Johnson, E. Tulkki, H., Hall, D.R., 2013, Needs Analysis for Language Course Design. A Holistic Approach to ESP, Cambridge.

Kickpatrick, A., 2007, World Englishes. Implications for international communication and English language teaching, Cambridge.

Lewandowski, M., 2014, "Gender stereotyping in EFL grammar textbooks. A diachronic approach", Linguistik online 68, 6/14, 83-99.

McDonough, J., Shaw, C., Masuhara, H., 2013, Materials and methods in ELT. A teacher's guide. Third edition, Oxford.

Mercer, N., 1996, English at work, in: Using English: from conversation to canon, eds. J. Maybin, N. Mercer, London, 84-108.

Michel, A., 1986, Down with Stereotypes! Eliminating sexism from children's literature and school textbooks, Paris.

Nickerson, C., 2005, "English as a lingua franca in international business contexts", English for Specific Purposes 24, 367-380.

Sercu, L., 1998, "In-service teacher training and the acquisition of the intercultural competence", in: Language Learning in Intercultural Perspective. Approaches through drama and ethnography, eds. M. Byram, M. Flemming, Cambridge, 255-289.

Seidlhofer, B., 2004, "Research perspectives in teaching English as a lingua franca", Annual Review of Applied Linguistics 24, 209-39.

Seidlhofer, B., 2005, "English as a lingua franca", ELT Journal 59(4), 339-341.

Şeker, M., Dinçer, A., 2014, "An Analysis of Gender Stereotyping in English Teaching Course Books", Çukurova University Faculty of Education Journal, 43(1), 90-98.

Sleeter, C., Grant, C., 1991, “ Race, Class, Gender and Disability in Current Textbooks", in: eds. W. Apple, L.K. Christian-Smith, London, 78-110.

Sowden, C., 2011, "EFL on a mushroom: the overnight growth in English as a Lingua Franca", ELT Journal 66 (1), 89-96.

Tanner, R., Green, C., 1998, Tasks for Teacher Education, Harlow.

Toprak, T.E., Aksoyalp, Y., 2014, “The Question of Re-Presentation In EFL Course Books: Are Learners of English Taught about New Zealand?", International Journal of Society, Culture E Language, November, 91-104.

Walker, R., 2015, "The globalization of English: implications for the language classroom", Modern English Teacher 24(2), 42-44.

Women in business and management: gaining momentum. 2015. Geneva: International Labour Office. Available at: http://www.ilo.org/wcmsp5/groups/ public/---dgreports/---dcomm/---publ/documents/publication/wcms_334 882.pdf. Accessed: 26.08.2015.

World Development Report 2012. Gender Equality and Development. 2011. Washington, DC: The World Bank. Available at: http://siteresources.world bank.org/INTWDR2012/Resources/7778105-1299699968583/7786210-1315 936222006/Complete-Report.pdf. Accessed: 22.08.2015. 
Zawadzka, E., 2004, Nauczyciel języków obcych w dobie przemian, Kraków.

Zhang, Z., 2013, “Teaching Business English", in: The encyclopedia of applied linguistics, ed. C.A. Chapelle, Oxford, 2.

\section{INTERNET SOURCES}

\section{INTERNET SOURCE 1:}

http://datatopics.worldbank.org/gender/key\%20gender\%20employment\%20in dicators. Accessed: 22.08.2015

INTERNET SOURCE 2:

http://www.econ.uj.edu.pl/studenci/sylabusy/ekonomia. Acessed: 18.11.2015

INTERNET SOURCE 3:

https://wsaib.pl/studenci/plan-studiow. Accessed: 18.11.2015.

INTERNET SOURCE 4:

https://weiz.po.opole.pl/download/sylabusy/adm1/adm1-ns-obowiazkowe.p

\section{THE IMAGE OF THE CORPORATE WORLD IN BUSINESS ENGLISH SPEAKING EXERCISES AT UPPER INTERMEDIATE LEVEL}

\section{Summary}

For pre-service students who have no professional experience, business English course books might become one of the main sources of information on how the corporate world communicates in English. Business English course books also provide students with an insight into the participation of men and women in international labour markets, as well as female and male positions on the corporate ladder. However, course books may understate the enormous variation in style and language which exists in the world of international business. They might also present a 'false' picture of gender roles in the labour market.

The article presents results of an analysis of the sections developing oral communication in selected business English course books, with regard to speaking skills and their transferability across various speakers, branches of industry, national and corporate cultures, the variety(ies) of English students are taught, as well as female and male positions in the world of international business.

Key words: business English, course book analysis, speaking exercises, speaking skills, corporate world, gender roles, tertiary language courses 


\section{OBRAZ ŚWIATA KORPORACYJNEGO W ĆWICZENIACH ROZWIJAJĄCYCH SPRAWNOŚĆ MÓWIENIA W WYBRANYCH PODRĘCZNIKACH DO JEZZYKA ANGIELSKIEGO BIZNESOWEGO NA POZIOMIE ŚREDNIOZAAWANSOWANYM WYŻSZYM}

\section{Streszczenie}

Dla osób, które uczą się języka angielskiego na lektoratach w szkołach wyższych i które nie posiadają doświadczenia zawodowego, podręczniki do języka angielskiego biznesowego mogą stać się jednym z głównych źródeł pokazujących w jaki sposób świat biznesu i korporacji międzynarodowych komunikuje się po angielsku. Podręczniki do języka angielskiego pokazują również uczącym się tego języka, jak wygląda sytuacja zawodowa kobiet i mężczyzn na międzynarodowych rynkach pracy i jakie pozycje zajmują kobiety i mężczyźni na szczeblach hierarchii korporacyjnej. Należy pamiętać jednak, że podręczniki do języka angielskiego biznesowego nie pokazują pełnego zróżnicowania językowego tak charakterystycznego dla międzynarodowego świata biznesu. Podręczniki te również pokazują nie do końca prawdziwy obraz mężczyzn i kobiet na rynku pracy.

Artykuł prezentuje wyniki analizy ćwiczeń rozwijających sprawność mówienia w wybranych podręcznikach do języka angielskiego biznesowego na poziomie średniozaawansowanym wyższym pod kątem ćwiczonych umiejętności (np. negocjowanie, small talk, cold calling, itd.), komunikacji formalnej i nieformalnej, rodzajów języka angielskiego (np. język angielski brytyjski, język angielski amerykański, itd.), oraz ról kobiet i mężczyzn w międzynarodowym świecie biznesu. Na końcu artykułu znajdują się wskazówki pedagogiczne, których celem jest pokazanie, jak należy pracować ze studentami szkół wyższych korzystającymi z podręczników do języka angielskiego biznesowego, tak aby obraz świata biznesowego kształtujący się trakcie lektoratów był jak najbardziej wierny rzeczywistości.

Słowa kluczowe: analiza podręczników, język angielski biznesowy, ćwiczenia na mówienie, świat biznesu, role kobiet i mężczyzn w świcie biznesu, lektorat 